Joyful Learning Journal

\title{
HUBUNGAN GERAKAN LITERASI SEKOLAH DAN MINAT BACA SISWA DENGAN HASIL BELAJAR IPS
}

\section{Retno Wulansari ${ }^{\bowtie}$, Drs. H. A. Zaenal Abidin, M.Pd}

Jurusan Pendidikan Guru Sekolah Dasar, Fakultas Ilmu Pendidikan, Universitas Negeri Semarang, Indonesia

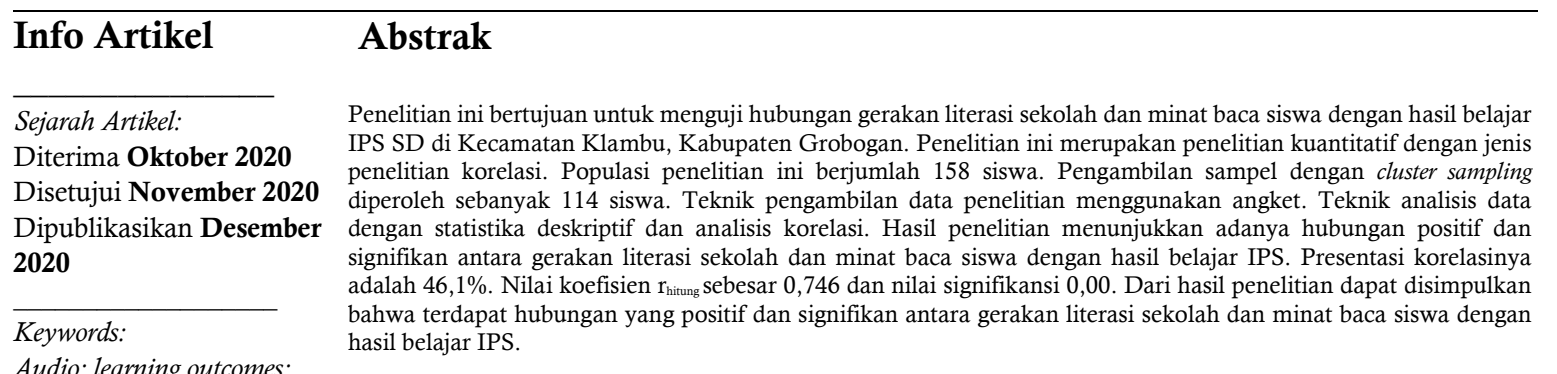

\begin{abstract}
This study aimed to examine the correlation between the school literacy movement and reading interest with social studies learning outcomes in Elementary School Klambu Subdistrict, Grobogan Regency. This was a quantitative study with the type of correlation research. The population of this study was 158 students. The sampling technique used cluster sampling of 114 students in total. The data collection technique used questionnaires. The data analysis techniques used descriptive statistics and correlation analysis. The result showed a positive and significant relationship between the school literacy movement and reading interest with social studies learning outcomes. The percentage of correlation was $46.1 \%$. The calculated coefficient $r$ count of 0.746 and a significance value of 0.00. From the results of the study it could be concluded that there is a positive and significant relationship between the school literacy movement and reading interest with the social studies learning outcomes.
\end{abstract}

\footnotetext{
Alamat korespondensi:

Taruman, RT/RW 03/01, Klambu, Kabupaten Grobogan.

E-mail: wulansariretno23@gmail.com
}

ISSN 2252-6366 


\section{PENDAHULUAN}

Pendidikan merupakan salah cara meningkatkan kualitas sumber daya manusia. Melalui pendidikan dapat menghasilkan generasi berintelektual, berbudaya dan berakhlak mulia. Pelaksanaan proses pendidikan tidak terlepas dari kurikulum pendidikan. Adanya kurikulum pendidikan diharapkan mampu menumbuhkan karakter positif dalam diri siswa. Karakter positif dapat dikembangkan melalui pembiasaan pembiasaan positif di lingkungan siswa. Hal ini berdasarkan Peraturan Menteri Pendidikan dan Kebudayaan Nomor 23 Tahun 2015 Pasal 1 Ayat 4 tentang Penumbuhan Budi Pekerti yang menyatakan bahwa salah satu cara menumbuhkan budi pekerti siswa dapat melalui pembiasaan. Pembiasaan merupakan serangkaian kegiatan yang harus dilakukan oleh siswa, guru dan tenaga kependidikan yang bertujuan untuk menumbuhkan kebiasaan yang baik dan membentuk generasi berkarakter positif.

Guna mengembangkan potensi siswa secara utuh dan menumbuhkan kebiasaan yang baik seperti kebiasaan membaca, pemerintah menggalakkan sebuah program Gerakan Literasi Sekolah. Menurut Kementerian Pendidikan dan Kebudayaan (dalam Abidin, 2018:279) menjelaskan Gerakan Literasi Sekolah merupakan suatu usaha atau kegiatan yang bersifat partisipasif guna membentuk warga masyarakat literat sepajang hayat dengan melibatkan seluruh warga sekolah dibawah koordinasi Direktorat Jenderal Pendidikan Dasar dan Menengah Kementerian Pendidikan dan Kebudayaan. Gerakan Literasi Sekolah merupakan gerakan sekolah guna meningkatkan minat baca siswa. Upaya yang ditempuh dalam melaksanakan Gerakan Literasi Sekolah berupa pembiasaan membaca pada diri siswa. Pembiasaan ini dilakukan melalui kegiatan membaca 15 menit sebelum pembelajaran dimulai.

Membaca merupakan salah satu kegiatan penting dalam proses pembelajaran. Setiap proses pembelajaran didasarkan pada kemampuan membaca. Menurut Tarigan (2015) membaca merupakan proses seseorang untuk mencari pesan yang terdapat dalam media tulis. Manfaat membaca yaitu memperoleh pengetahuan dan wawasan baru untuk meningkatkan kecerdasan seseorang (Rahim, 2011). Manfaat membaca tidak akan diperoleh jika tidak memiliki minat baca. Minat baca merupakan keinginan yang kuat terhadap kegiatan membaca, orang yang memiliki minat baca kuat akan diwujudkan dengan kesediaannya mencari bahan bacaan atas kesadaran dan kemauan diri sendiri (Dalman, 2017). Dengan demikian, minat baca siswa perlu ditingkatkan agar penguasaan ilmu pengetahuan semakin luas.

Setiap muatan pembelajaran membutuhkan kegiatan membaca, termasuk muatan pembelajaran Ilmu Pengetahuan Sosial (IPS). Munisah, dkk (2018) menyatakan tujuan pembelajaran IPS yaitu menumbuhkan pengetahuan dan sikap tanggung jawab melalui kepedulian terhadap lingkungan. Tercapainya tujuan pembelajaran IPS dapat diukur melalui hasil belajar siswa. Perubahan hasil belajar mencakup perubahan pada aspek kognitif (pengetahuan), aspek afektif (sikap) dan aspek psikomotorik (keterampilan) (Susanto, 2013).

Berdasarkan penilaian yang dilakukan oleh The Programme for International Student Assessment (PISA) pada tahun 2018, kemampuan membaca siswa di Indonesia masih tergolong rendah jika dibandingkan dengan negara lain. Indonesia menempati posisi ke-72 dari 78 negara dengan jumlah poin sebanyak 396.

Permasalahan tersebut juga terjadi di kela V SD Negeri Kecamatan Klambu Kabupaten Grobogan. Berdasarkan nilai PTS semester 1 tahun ajaran 2019/2020, menunjukkan bahwa sebanyak 74 siswa (47\%) belum mencapai KKM pada muatan pembelajaran IPS. Berdasarkan hasil observasi, angket siswa dan wawancara guru kelas V, menjelaskan Gerakan Literasi Sekolah masih kurang optimal karena keterbatasan waktu dan banyaknya materi pelajaran yang harus diselesaikan, minat baca siswa bervariasi yang diketahui dari total 158 siswa yang senang membaca sebanyak 94 siswa dan yang tidak senang membaca sebanyak 64 siswa. Dari hasil identifikasi tersebut, ditemukan permasalahan yang mempengaruhi perolehan hasil belajar IPS antara lain Gerakan Literasi Sekolah yang kurang optimal dan minat baca siswa yang bervariasi. Permasalahan ini dapat diatasi dengan meningkatkan minat baca siswa melalui program pembiasan membaca yang dapat memberikan wawasan dan pengetahuan baru sehingga siswa mampu meningkatkan hasil belajar.

Guna memperkuat peneliti mengkaji Gerakan Literasi Sekolah, minat baca dan hasil belajar, berikut penelitian relevan yang dilakukan oleh Graham Steve (2017) berjudul Effectiveness of Literacy Programs Balancing Reading and Writing Instruction: A Meta-Analysis, hasil penelitian menunjukkan terdapat pengaruh program literasi terhadap peningkatan kemampuan membaca. Selanjutnya penelitian oleh Laela Safitri, Aji Heru Muslim dan Santhy Hawanti (2019) berjudul Pengaruh Membaca 15 Menit terhadap Minat Baca Siswa Sekolah Dasar, hasil penelitian menunjukkan minat baca tinggi dapat terjadi karena terbiasa membaca buku sebelum pembelajaran dimulai. 
Kemudian penelitian Wahyu Rangga Raditya (2016) berjudul Hubungan Minat Baca dengan Prestasi Belajar IPS Siswa Kelas V SD Gugus III Seyegan, hasil penelitian menjelaskan minat baca dapat mempengaruhi hasil belajar siswa.

Berdasarkan latar belakang tersebut, peneliti memandang penelitian ini sangat penting diteliti agar dapat menambah kajian mengenai Gerakan Literasi Sekolah, minat baca dan hasil belajar. Oleh sebab itu, perlu diadakan kajian dalam bentuk penelitian dengan judul "Hubungan Gerakan Literasi Sekolah dan Minat Baca Siswa dengan Hasil Belajar IPS SD Negeri Kecamatan Klambu Kabupaten Grobogan".

Tujuan penelitian ini adalah (1) menguji hubungan Gerakan Literasi Sekolah dan hasil belajar IPS; (2) menguji hubungan minat baca siswa dengan hasil belajar IPS; (3) menguji hubungan Gerakan Literasi Sekolah dan minat baca siswa dengan hasil belajar IPS.

\section{METODE PENELITIAN}

Metode penelitian ini adalah penelitian kuantitatif dengan desain penelitian korelasi. Populasi penelitian ini siswa kelas V SD Negeri Kecamatan Klambu Kbupaten Grobogan yang terdiri dari 8 sekolah dasar. Kemudian dipilih secara acak sebanyak 7 yaitu SD Negeri 1 Klambu, SD Negeri 2 Klambu, SD Negeri 3 Klambu, SD Negeri 4 Klambu, SD Negeri 3 Terkesi, SD Negeri 1 Menawan dan SD Negeri 2 Menawan dengan jumlah siswa sebanyak 158 pada tahun ajaram 2019/2020. Pengambilan sampel dalam penelitian ini menggunakan teknik probability sampling yaitu cluster random sampling. Variabel penelitian terdiri dari: (1) variabel bebas yaitu Gerakan Literasi Sekolah dan minat baca; (2) variabel terikat yaitu hasil belajar IPS.

Metode pengumpulan data menggunakan observasi, wawancara, dokumentasi dan angket. Sebelum instrumen angket digunakan, peneliti menguji validitas dan reabilitas instrumen di SDN 1 Terkesi dan SDN 4 Kandangrejo dengan jumlah responden sebanyak 35 siswa. Uji coba validitas instrumen menggunakan rumus Pearson Product Moment dengan bantuan program SPPS for Windows Seri 21, hasil uji validitas diperoleh nilai $\mathrm{r}_{\text {hitung }}>\mathrm{r}_{\text {tabel }}$ $=0,334$ pada taraf dignifikansi $5 \%$, sehingga diperoleh 31 pernyataan Gerakan Literasi Sekolah dan 30 pernyataan minat baca dinyatakan valid. Pengujian reabilitas mengunakan rumus Alpha Cronbach dengan bantuan program SPPS for Windows Seri 21 yang menghasilkan $r_{11}$ Gerakan Literasi Sekolah sebesar 0,884 dan $\mathrm{r}_{11}$ minat baca sebesar 0,867. Jika diinterpretasikan dengan nilai $r$, nilai reabilitas Gerakan Literasi Sekolah dan minat baca tergolong sangat tinggi.

Uji prasyarat analisis data dilakukan dengan uji normalitas, uji linieritas, uji multikolinieritas, uji heterokesdastisitas, dan uji autokorelasi. Setelah memenuhi uji prasyarat, selanjutnya data dianalisis dengan statistik desktiptif, dan dianalisis hipotesis menggunakan analisis korelasi sederhana, analisis korelasi berganda, uji $\mathrm{F}$, analisis regresi linier sederhana, dan analisis regresi ganda.

\section{HASIL PENELITIAN DAN PEMBAHASAN}

\section{Hasil Analisis Deskriptif Gerakan Literasi Sekolah $\left(\mathbf{X}_{1}\right)$}

Data analisis deskriptif Gerakan Literasi Sekolah diperoleh dari angket yang terdiri dari 31 pernyataan dengan empat pilihan jawaban (sangat benar, benar, tidak benar dan sangat tidak benar). Hasil analisis deskriptif sebagai berikut:

Tabel 1 Data Gerakan Literasi Sekolah

\begin{tabular}{llllcl}
\hline No & Interval & Kategori & Frekuens $\begin{array}{c}\text { Persentase } \\
\text { (\%) }\end{array}$ & $\begin{array}{c}\text { Rata } \\
\text { rata }\end{array}$ \\
\hline 1. & $84-97$ & Sangat Baik & 38 & $33,3 \%$ & 76 \\
2. & $70-83$ & Baik & 40 & $35,1 \%$ & \\
3. & $56-69$ & Cukup & 33 & $28,9 \%$ & \\
4. & $42-55$ & Kurang & 3 & $2,6 \%$ & \\
& Jumlah & & $\mathbf{1 1 4}$ & $\mathbf{1 0 0 \%}$ & Baik \\
\hline
\end{tabular}

\section{Hasil Analisis Deskriptif Minat Baca Siswa $\left(\mathrm{X}_{2}\right)$}

Data analisis deskriptif minat baca diperoleh dari angket yang terdiri dari 30 pernyataan dengan empat pilihan jawaban (sangat benar, benar, tidak benar dan sangat tidak benar). Hasil analisis deskriptif sebagai berikut:

Tabel 2 Data Minat Baca Siswa

\begin{tabular}{lllccc}
\hline No & Interval & Kategori & Frekuens $\begin{array}{c}\text { Persentase } \\
\text { (\%) }\end{array}$ & $\begin{array}{c}\text { Rata } \\
\text { rata }\end{array}$ \\
\hline 1. & $84-97$ & Sangat Tinggi 25 & $21,9 \%$ & 76 \\
2. & $70-83$ & Tinggi & 31 & $27,2 \%$ & \\
3. & $56-69$ & Sedang & 40 & $31,1 \%$ & \\
4. & $42-55$ & Rendah & 18 & $15,8 \%$ & \\
& Jumlah & & $\mathbf{1 1 4}$ & $\mathbf{1 0 0 \%}$ & Tinggi \\
\hline
\end{tabular}

Hasil Analisis Deskriptif Hasil Belajar IPS (Y)

Hasil belajar siswa ranah kognitif muatan pembelajaran IPS. Data diperoleh dari dokumentasi nilai PTS semester 2 tahun ajaran 2019/2020. Nilai hasil belajar dikelompokkan menurut permendikbud No. 53 Tahun 2015. 
Berdasarkan pengolahan data diperoleh hasil sebagai berikut:

Tabel 3 Data Hasil Belajar IPS (Ranah Kognitif)

\begin{tabular}{|c|c|c|c|c|}
\hline $\begin{array}{l}\text { Rentang } \\
\text { Nilai }\end{array}$ & Kategori & Frekuensi & $\begin{array}{l}\text { Persentase } \\
(\%)\end{array}$ & Rata-rata \\
\hline $80-100$ & $\begin{array}{l}\text { Sangat } \\
\text { Memuaskan }\end{array}$ & 87 & $76,3 \%$ & 82 \\
\hline $70-79$ & Memuaskan & 22 & $19 \%$ & \\
\hline $60-69$ & $\begin{array}{l}\text { Cukup } \\
\text { Memuaskan }\end{array}$ & 5 & $4,7 \%$ & \\
\hline $50-59$ & $\begin{array}{l}\text { Kurang } \\
\text { Memuaskan }\end{array}$ & 0 & $0 \%$ & \\
\hline \multirow[t]{2}{*}{$0-49$} & $\begin{array}{l}\text { Sangat Kurang } \\
\text { Memuaskan }\end{array}$ & 0 & $0 \%$ & \\
\hline & Jumlah & 114 & $100 \%$ & $\begin{array}{l}\text { Sangat } \\
\text { Memuaskan }\end{array}$ \\
\hline
\end{tabular}

\section{Hasil Uji Prasyarat Analisis Data Hasil Uji Normalitas}

Hasil uji normalitas menunjukkan nilai Asymp. Sig. (2-tailed) sebesar 0,386. Pengambilan keputusan adalah nilai signifikansi $>\alpha(0,05)$. Dengan demikian dapat disimpulkan Gerakan Literasi Sekolah, minat baca dan hasil belajar IPS berdistribusi normal.

\section{Hasil Uji Linieritas}

Uji linieritas variabel Gerakan Literasi Sekolah dan hasil belajar IPS memperoleh nilai signifikansi $(0,000)<\alpha(0,05)$, sehingga hubungan Gerakan Literasi Sekolah dan hasil belajar IPS bersifat linier. Uji linieritas variabel minat baca dan hasil belajar IPS memperoleh nilai signifikansi $(0,000)<\alpha(0,05)$, sehingga hubungan minat baca dan hasil belajar IPS bersifat linier.

\section{Hasil Uji Multikolinieritas}

Hasil uji multikolinieritas nilai VIF sebesar $1,817<10$ dan nilai tolerance sebesar $0,550>0,1$, maka dapat disimpulkan bahwa tidak ada hubungan multikolinieritas antara variabel Gerakan Literasi Sekolah dan minat baca.

\section{Hasil Uji Heterokedastisitas}

Uji heteroskedastisitas variabel Gerakan Literasi Sekolah memperoleh nilai signifikansi sebesar $0,779>0,05$, maka dapat disimpulkan tidak terdapat masalah heteroskedastisitas. Pada variabel minat baca nilai signifikansi sebesar $0,750>0,05$, maka dapat disimpulkan tidak terdapat masalah heteroskedastisitas.

\section{Hasil Uji Autokorelasi}

Hasil uji autokorelasi diperoleh nilai $\mathrm{DW}=1,538, \quad \mathrm{dU}=1,7303$ dan 4-dU=2,2697. Sehingga diperoleh dU $(1,7303)<$ DW $1,538<$ 4 - dU (2,2697), maka dapat disimpulkan
Gerakan Literasi Sekolah $\left(\mathrm{X}_{1}\right)$, minat baca $\left(\mathrm{X}_{2}\right)$ dan hasil belajar IPS (Y) tidak terjadi autokorelasi.

\section{Hasil Uji Hipotesis}

Hubungan Gerakan Literasi Sekolah dengan
Hasil Belajar IPS SD Negeri Kecamatan
Klambu Kabupaten Grobogan

Tabel 4 Hasil Analisis $\mathrm{X}_{1}$ dan $\mathrm{Y}$

\begin{tabular}{cccccccc}
\hline $\mathbf{r}_{\text {hitung }}$ & $\mathbf{r}_{\text {tabel }}$ & $\mathbf{F}_{\text {hitung }}$ & $\mathbf{F}_{\text {tabel }}$ & $\mathbf{r}$ & $\mathbf{R}$ & $\mathbf{a}$ & $\mathbf{b}$ \\
\hline 0,651 & 0,1981 & 82,381 & 3,93 & 0,651 & 0,424 & $47,6790,372$
\end{tabular}

Berdasarkan tabel 4 menunjukkan adanya hubungan yang kuat antara Gerakan Literasi Sekolah $\left(\mathrm{X}_{1}\right)$ dengan hasil belajar IPS, dilihat dari $\mathrm{r}_{\text {hitung }}(0,651)$ berada pada interval 0,600 0,799 dengan arah hubungan positif. Karena nilai r positif, maka semakin baik keikutsertaan siswa dalam melaksanakan Gerakan Literasi Sekolah, akan semakin memuaskan hasil belajar IPS. Selain itu, nilai $F_{\text {hitung }}=82,381$ dan nilai $F_{\text {tabel }}=3,93$. Sehingga $F_{\text {hitung }}>F_{\text {tabel }}$ artinya $\mathrm{Ha}_{1}$ diterima, maka terdapat hubungan yang signifikan antara Gerakan Literasi Sekolah dengan hasil belajar IPS. Selanjutnya nilai koefisien determinasi sebesar 0,424. Artinya Gerakan Literasi Sekolah memberikan dampak positif sebesar $42,4 \%$ dengan hasil belajar IPS. Persamaan regresi linier sederhana Gerakan Literasi Sekolah dan hasil belajar IPS adalah $\hat{Y}$ $=47,679+0,372 \mathrm{X}_{1}$ yang memiliki arti bahwa setiap perubahan satu skor Gerakan Literasi Sekolah menyebabkan perubahan perbaikan nilai hasil belajar IPS sebesar 0,372 ke arah positif.

Hal ini diperkuat dengan pendapat Mulyati (dalam Aptensi, 2017) yang menyatakan bahwa kebiasaan membaca dapat mempengaruhi hasil belajar, hal ini bergantung pada kualitas dan kuantitas bacaan. Menurut Anna H. Hall dkk (2015) menjelaskan bahwa untuk meningkatkan kemampuan literasi, perlu memperhatikan lingkungan siswa yang kaya akan print. Wahyuni (2018) menjelaskan bahwa siswa yang senang membaca akan memiliki pengetahuan yang luas, sehingga dapat mengoptimalkan hasil belajar yang diperoleh.

Hasil analisis diperkuat dengan penelitian Ririn Nuryanti (2019) yang berjudul Pengaruh Kualitas Pelaksanaan Gerakan Literasi dan Minat Baca terhadap Hasil Belajar Berbicara Siswa SD Negeri Se-Gugus Taman Kota Madiun, hasil penelitian menunjukkan bahwa semakin berkualitas pelaksanaan gerakan literasi maka hasil belajar semakin meningkat. Selanjutnya penelitian oleh Susi 
Hermin Rusminati dan Cholifah Tur Rosidah (2018) berjudul Korelasi Penerapan Gerakan Literasi Sekolah (GLS) dengan Kemampuan Menyelesaikan Soal Cerita Matematika Siswa Di SDN Kebondalem Mojosari dan SDN Ketabang Surabaya, hasil penelitian menunjukkan adanya hubungan yang positif dari penerapan Gerakan Literasi Sekolah dengan kemampuan siswa dalam menyelesaikan soal cerita matematika.

Dengan demikian dapat disimpulkan bahwa Gerakan Literasi Sekolah dapat berpengaruh terhadap hasil belajar. Semakin baik pelaksanaan siswa dalam melaksanakan Gerakan Literasi Sekolah maka semakin memuaskan hasil belajar siswa kelas V SD Negeri Kecamatan Klambu Kabupaten Grobogan, begitupun sebaliknya.

Hubungan Minat Baca Siswa dengan Hasil Belajar IPS SD Negeri Kecamatan Klambu Kabupaten Grobogan

Tabel 5 Hasil Analisis $X_{2}$ dan $Y$

$\begin{array}{llllllll}\mathbf{r}_{\text {hitung }} & \mathbf{r}_{\text {tabel }} & \mathbf{F}_{\text {hitung }} & \mathbf{F}_{\text {tabel }} & \mathbf{r} & \mathbf{R} & \mathbf{a} & \mathbf{b}\end{array}$

$0,707 \quad 0,1981 \quad 112,1163,93 \quad 0,707 \quad 0,50045,2250,415$

Berdasarkan tabel 5 menunjukkan adanya hubungan yang kuat antara minat baca $\left(\mathrm{X}_{2}\right)$ dengan hasil belajar IPS, dilihat dari $r_{\text {hitung }}$ $(0,707)$ berada pada interval 0,600-0,799 dengan arah hubungan positif. Karena nilai $r$ positif, maka semakin tinggi minat baca siswa akan semakin memuaskan hasil belajar IPS. Selain itu, nilai $\mathrm{F}_{\text {hitung }}=112,116$ dan nilai $\mathrm{F}_{\text {tabel }}=$ 3,93. Sehingga $F_{\text {hitung }}>F_{\text {tabel }}$ artinya $\mathrm{Ha}_{2}$, maka terdapat hubungan yang signifikan antara minat baca dengan hasil belajar IPS. Selanjutnya nilai koefisien determinasi sebesar 0,500. Artinya minat baca memberikan dampak positif sebesar $50,0 \%$ dengan hasil belajar IPS. Persamaan regresi linier sederhana minat baca dan hasil belajar IPS adalah $\mathrm{Y}^{\prime}=45,225+0,415 \mathrm{X}_{2}$ yang artinya bahwa setiap perubahan satu skor minat baca menyebabkan perubahan perbaikan nilai hasil belajar IPS sebesar 0,415 ke arah positif.

Hal ini diperkuat dengan pendapat Slameto (2013) yang menyatakan bahwa salah satu faktor yang dapat mempengaruhi hasil belajar adalah minat. Menurut Antika (2017) minat baca mampu memperluas pengetahuan, semakin tinggi minat baca siswa maka semakin tinggi hasil belajar yang diterima. Selanjutnya Hartono (dalam Murtiningsih, 2018) menjelaskan minat baca dapat mempengaruhi hasil belajar, hal ini disebabkan seseorang yang memiliki minat baca tingi akan memiliki pengetahuan dan wawasan yang luas, sehingga dapat mendukung hasil belajar, begitupun sebaliknya.

Penelitian lain yang mendukung yaitu penelitian Lia Murtiningsih (2018) berjudul Pengaruh Minat Baca Terhadap Hasil Belajar IPS Siswa SD Kelas V Se-Gugus Kusuma, hasil penelitian menunjukkan adanya pengaruh yang signifikan antara minat baca dan hasil belajar. Selanjutnya penelitian oleh W Gusmayanti, RSP Fauziah, dan I Muhdiyati (2018) berjudul Pengaruh Minat Membaca Cerita Pahlawan pada Hasil Pengajaran, hasil penelitian menjelaskan adanya hubungan yang positif antara minat baca dan hasil belajar, semakin tinggi minat baca akan semakin tinggi hasil belajar yang diperoleh.

Dengan demikian dapat disimpukan bahwa minat baca dapat berpengaruh terhadap hasil belajar. Semakin tinggi minat baca siswa maka semakin memuaskan hasil belajar siswa kelas V SD Negeri Kecamatan Klambu Kabupaten Grobogan, begitupun sebaliknya.

Hubungan Gerakan Literasi Sekolah dan Minat Baca Siswa dengan Hasil Belajar IPS SD Negeri Kecamatan Klambu Kabupaten Grobogan

Tabel 6 Hasil Analisis $\mathrm{X}_{1}$ dan $\mathrm{X}_{2}$ dengan $\mathrm{Y}$

\begin{tabular}{llllllll}
\hline $\mathbf{r}_{\text {hitung }}$ & $\mathbf{r}_{\text {tabel }}$ & $\mathbf{F}_{\text {hitung }}$ & $\mathbf{F}_{\text {tabel }}$ & $\mathbf{r}$ & $\mathbf{R}$ & $\mathbf{a}$ & $\mathbf{b}$
\end{tabular}

$\begin{array}{lllllllll}0,746 & 0,557 & 69,793 & 3,08 & 0,679 & 0,461 & 69,623 & 0,098\end{array}$

Berdasarkan tabel 6 menunjukkan nilai $r_{\text {hitung }}(0,746)>r_{\text {tabel }}(0,557)$, maka dapat disimpulkan adanya hubungan antara Gerakan Literasi Sekolah dan minat baca secara bersama-sama dengan hasil belajar IPS dengan tingkat hubungan yang kuat. Selain itu, nilai $F_{\text {hitung }}=69,793$ dan nilai $F_{\text {tabel }}=3,08$. Sehingga $F_{\text {hitung }}>\mathrm{F}_{\text {tabel }}$ artinya $\mathrm{Ha}_{3}$ diterima, maka terdapat hubungan yang signifikan antara Gerakan Literasi Sekolah dan minat baca dengan hasil belajar IPS. Selanjutnya nilai koefisien determinasi sebesar 0,461 atau 46,1\%. Artinya Gerakan Literasi Sekolah dan minat baca secara bersama-sama memberikan dampak positif dengan hasil belajar IPS sebesar 46,1\%. Persamaan regresi ganda Gerakan Literasi Sekolah dan minat baca dengan hasil belajar IPS adalah $Y^{\prime}=69,623+0,098 X_{1}+0,180 X_{2}$ yang artinya setiap perubahan satu skor Gerakan Literasi Sekolah akan menyebabkan perubahan satu skor hasil belajar IPS sebesar 0,098 dan setiap penambahan satu skor minat baca akan menyebabkan perubahan satu skor hasil belajar IPS sebesar 0,180.

Hal ini diperkuat dengan pendapat Nuryanti (2019:116) yang menyatakan ada banyak faktor yang dapat mempengaruhi hasil 
belajar, faktor tersebut diantaranya kualitas pelaksanaan Gerakan Literasi Sekolah dan minat baca siswa. Gerakan Literasi Sekolah yang berkualitas dapat meningkatkan minat baca siswa yang pada akhirnya dapat mempengaruhi hasil belajar siswa. Stephen Ciullo, dkk (2016) menjelaskan bahwa kegiatan literasi dapat diimplementasikan menjadi beberapa macam, diantaranya pembagian alokasi waktu untuk mengerjakan tugas dibidang akademik dan non akademik, pemberian waktu khusus bagi siswa untuk membaca, pengelompokkan kelas untuk membaca dan menyediakan bahan bacaan baik secara tertulis maupun elektronik. Dengan berbagai kegiatan literasi tersebut, diharapkan dapat menumbuhkan minat baca siswa yang dapat berpengaruh pada naiknya hasil belajar yang diterima.

Penelitian lain yang mendukung yaitu penelitian oleh Afifi Rengiwur (2018) yang berjudul Pengaruh Program Literasi Sekolah Terhadap Minat Membaca dan Hasil Belajar IPA Siswa SMA Negeri Kota Tual. Hasil penelitian menunjukkan bahwa terdapat pengaruh yang signifikan antara program literasi sekolah dengan minat baca dan terdapat pengaruh yang signifikan antara program literasi sekolah dengan hasil belajar.

Dengan demikian dapat disimpulkan bahwa Gerakan Literasi Sekolah dan minat baca secara bersama-sama dapat mempengaruhi hasil belajar. Semakin baik pelaksanaan siswa dalam melaksanakan Gerakan Literasi Sekolah dan semakin tinggi minat baca siswa, maka akan semakin memuaskan hasil belajar yang didapatkan siswa kelas V SD Negeri Kecamatan Klambu Kabupaten Grobogan.

\section{SIMPULAN}

Berdasarkan hasil penelitian sesuai dengan permasalahan yang ada dilapangan, ama dapat disimpulkan bahwa; (1) Terdapat hubungan yang positif dan signifikan antara Gerakan Literasi Sekolah dengan hasil belajar IPS yang ditunjukkan dengan nilai $r_{\text {hitung }}(0,651)$ $>r_{\text {tabel }}(1,981)$ dengan pengaruh sebesar $42,4 \%$; (2) Terdapat hubungan yang positif dan signifikan antara minat baca dengan hasil belajar IPS yang ditunjukkan dengan nilai $r_{\text {hitung }}$ $(0,707)>r_{\text {tabel }}(1,981)$ dengan pengaruh sebesar $50 \%$; (3) Terdapat hubungan yang positif dan signifikan antara Gerakan Literasi Sekolah dan minat baca secara bersama dengan hasil belajar IPS yang ditunjukkan dengan nilai $r_{\text {hitung }}(0,746)$ $>r_{\text {tabel }}(1,981)$ dengan pengaruh sebesar $46,1 \%$.

\section{UCAPAN TERIMAKASIH}

Ucapan terimakasih disampaikan kepada Drs. H. A. Zaenal Abidin, M.Pd selaku dosen pembimbing yang telah memberikan bimbingan dan masukan dalam penyusunan manuskrip ini. Serta Dr. Eko Purwanti, M.Pd. dan Dra. Munisah, M.Pd selaku mitra bestari yang telah memberikan bimbingan dan koreksi pada manuskrip ini.

\section{DAFTAR PUSTAKA}

Abidin, Y. dkk. 2018. Pembelajaran Literasi. Jakarta: Bumi Aksara

Antika, L. 2017. Hubungan Antara Minat Baca dan Hasil Belajar Siswa Biologi Siswa yang Diajar dengan Model ReadingConcept Map-Think Pair Share (REMAP TPS). Jurnal Didaktika. 5(1): 28-35

Aptensi, F., Yuliantini, N., \& Lukman. 2017. Hubungan Kebiasaan Membaca dengan Hasil Belajar Bahasa Indonesia Siswa Kelas IV SDN 17 Kota Bengkulu. Jurnal PGSD, 1(1), 34-42

Ciullo, S., ect. 2016. Implementation of EvidenceBased Literacy Practices in Middle School Response to Intervention: An Observation Study. International Journal of Learning Disability Quarterly. 39(1): 44-57

Dalman. 2017. Keterampilan Membaca. Jakarta: Rajawali Pers

Gusmayanti, W., Fauziah, R., \& Muhdiyati, I. 2018. Pengaruh Minat Membaca Cerita Pahlawan pada Hasil Pengajaran. Jurnal Didaktika Tauhidi. 5(2): 123-135

Hall, H.A., ect. 2015. Examining the Effects of Preschool Writing Instruction on Emergent Literacy Skills: A Systematic Review of the Literature. International Journal of Literacy Research and Instruction. $0(0): 1-20$

Murtiningsih, L. 2018. Pengaruh Minat Baca Terhadap Hasil Belajar IPS Siswa SD Kelas V Se-Gugus Kusuma. Jurnal Pendidikan Guru Sekolah Dasar. 40(7): 4.009-4.018

Nuryanti, R. 2019. Pengaruh Kualitas Pelaksanaan Gerakan Literasi dan Minat Baca Terhadap Hasil Belajar Berbicara Siswa SD Negeri Segugus Taman, Kota 
Madiun. Jurnal Linguista (Jurnal Ilmiah, Bahasa dan Sastra). 3(2): 105-119

Peraturan Menteri Pendidikan dan Kebudayaan Nomor 23 Tahun 2015 Pasal 1 Ayat 4 tentang Penumbuhan Budi Pekerti

Raditya, A. 2016. Hubungan Minat Baca Dengan Prestasi Belajar IPS Siswa Kelas V SD Gugus III Seyegan. Jurnal Pendidikan Guru Sekolah Dasar. 1(5): 64-71

Rahim, F. 2011. Pengajaran Membaca di Sekolah Dasar. Jakarta: Bumi Aksara

Rengiwur, A. 2018. Pengaruh Program Literasi Sekolah Terhadap Minat Membaca dan Hasil Belajar IPA Siswa SMA Negeri Kota Tual. Prosiding Seminar Nasioal. Jakarta 2-4 Juni 2018

Rusminati, H \& Rosidah, T. 2018. Korelasi Penerapan Gerakan Literasi Sekolah (GLS) dengan Kemampuan Menyelesaikan Soal Cerita Matematika Siswa di SDN Kebondalem Mojosari dan SDN Ketabang Surabaya. Jurnal Inventa. 5(2): 97-103

Safitri, L., Muslim, H., \& Hawanti, S. 2019. Pengaruh Membaca 15 Menit terhadap
Minat Baca Siswa Sekolah Dasar. Jurnal Cakrawala Pendas. 5(2): 153-157

Slameto. 2015. Belajar dan Faktor-faktor yang Mempengaruhi. Jakarta: Rineka Cipta

Steve, G., ect. 2017. Effectiveness of Literacy Programs Balancing Reading and Writing Instruction: A Meta- Analysis. International Journal of Reading Research Quarterly. 0(0): 1-26

Sugiyono. 2016. Statistika untuk Penelitian. Bandung: Alfabeta

Sunyoto, D. 2011. Analisis Regresi dan Uji Hipotesis. Yogyakarta: CAPS

Susanto, A. 2015. Teori Belajar Pembelajaran. Jakarta: Prenadamedia Group

Tarigan, G. 2015. Membaca sebagai Suatu Keterampilan Berbahasa. Bandung: CV Angkasa

Wahyuni, D., Djatmika, T., \& As'ari, R. 2018. Pengaruh Full Day School dan Gerakan Literasi Sekolah terhadap Hasil Belajar dengan Mediasi Motivasi Belajar. Jurnal Pendidikan. 3(5): 679-684 